Ann. Zootech., I980, 29 (2), 93-102.

\title{
The training of drakes for semen collection
}

\author{
N.S. TAN \\ Department of Animal Science and Production, University of Western Australia \\ Nedlands, Western Australia 6009
}

\section{Sum mary}

One hundred and seventy-two drakes of two genera (Muscovy and Pekin), at various ages, were trained for semen collection over three breeding seasons. The laying Muscovy female is used as the teaser since she is receptive to both the Muscovy and Pekin drakes. The training process exploits a number of innate and conditioned reflexes in the drakes. During the initial training and subsequent active collection period, the drakes learn to overcome the external and internal inhibitions by the arousal and gratification of their sexual urge. Pretraining management had a significant effect $(P<$ o.ooI) on the training success of the Muscovy males. Males which came into contact with the collectors at 16 weeks and at puberty had a success rate of training of $9 \mathrm{I} .7 \mathrm{p}$. I oo and $83.3 \mathrm{p}$. roo respectively compared with $\mathrm{r} 6.7 \mathrm{p}$. Ioo for adult flock males. For the Pekin, however, the effect of pre-training management was not significant.

\section{Introduction}

Natural mating between Muscovy (Cairina moschata) $\times$ Pekin (Anas platyrhynchos) results in poor fertility (KALINA, I958; WATANABE, I959; TAN, I97I; CASsagne et al., I973; STEKLEN'Ov, Kromin and Gavrish, i976). Artificial insemination (AI) is a logical alternative. The massage and manual methods (ONISHI and Kato, I955; WaTANABE, I959, I961; KAMAR, I962) and electroejaculation (WATANABE, I957, I96I) have been used on the Muscovy drakes with limited success. Nishiyama, Nakashima and Fukihara (I976) collected semen from four Pekin drakes with an artificial vagina similar to that used for farm animals. The average semen volume/ejaculate and sperm concentration was $0.39 \mathrm{ml}$ and $9.46 \times \mathrm{IO}^{9} / \mathrm{ml}$ respectively. These figures are much higher than the figures reported in the literature for semen characteristics of Pekin drakes collected either by massage (Kamar, I962; Chemmonska and Gaiuszkowa, I966; PINGEL, I972) or electro-ejaculation (Chelmonska, GALUSZKA and LISIECKI, ig62). However, Nishiyama, Nakashima and Fukihara (I976) did not give 
any information on the training of the Pekin drakes for semen collection and its success rate. Similarly, there is no information in the literature on this topic for Muscovy males. However, for the practical use of AI there is a need for a detailed description of the method used for semen collection and the training procedure which allows for a reliable use of the males.

\section{I. - Sexual Behaviour in Ducks}

The sexual act itself consists of stages which may be regarded separately for analysis although there is a continuity between them. The following five stages may be readly distinguished in the drake :

I. Courtship.

2. Mounting and positioning.

3. Evagination of the penis and stimulation of the lemale.

4. Intromission, erection and ejaculation.

5. Post-coital display.

The completion of the mating act as a whole and its stages, depends upon the sexual libido and the mating technique of both the individuals involved.

\section{I. - Courtship}

Courtship tends to be elaborate and lengthy for birds which form pairs (LOREnZ, I95I; WOOD-Gush, I954, I956). It serves to excite the female (ScHu'TZ, I965) as well as being self-stimulatory for the male (KERRUISH, I955).

In the Pekin, mating is preceded by courtship, although in a reduced form compared to its ancestor, the Wild Mallard, but mating is always preceded by head pumping.

Muscovys do not form pairs in the wild state, the males being promiscuous (LORENZ, I953; DeLACOUR, I964). Little or no courtship occurs before mating. However, as an adaptation to the behaviour of the Muscovy drake, the receptive duck will crouch and remain in that position when the drake makes a grab at her.

\section{2. - Mounting and positioning}

The drake mounts and seizes the nape of the duck. It then positions itself exerting a massage-like motion with its feed upon the ilio-femoral region of the duck. The weight of the male, together with the massage action, pushes the vagina of the duck towards its vent.

\section{3. - Evagination of the penis and location of the vagina}

While exerting the massage motion on the duck's back, the male also evaginates its penis from a membranous fold in the ventral wall of the cloaca (WATANABE, I96I). The drake then swings its tail in from the left side of the duck and with pendulum novements, stimulates and locates the slightly evaginated vent. 

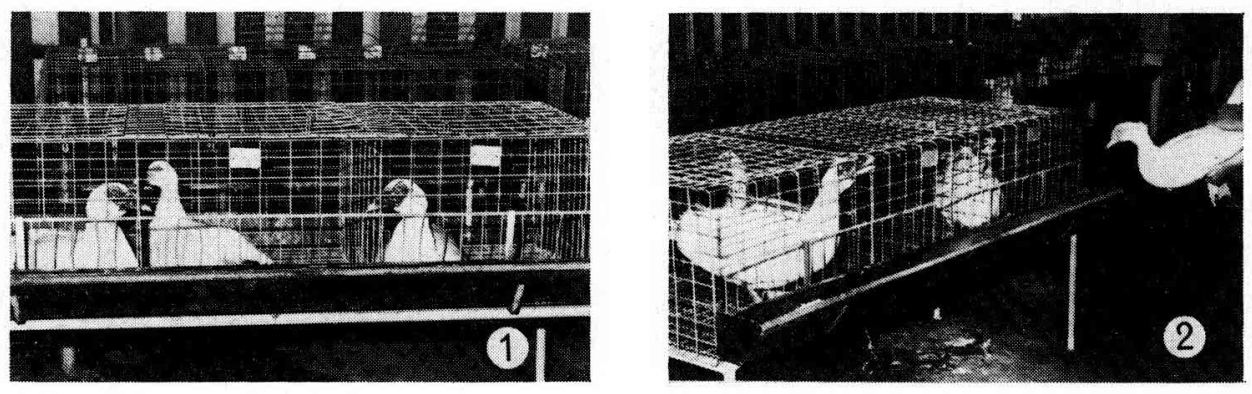

PHOTO I. Muscovy males in non excited state.

pHOTO 2. Muscovy males showing excitement when approached by cclector with duck
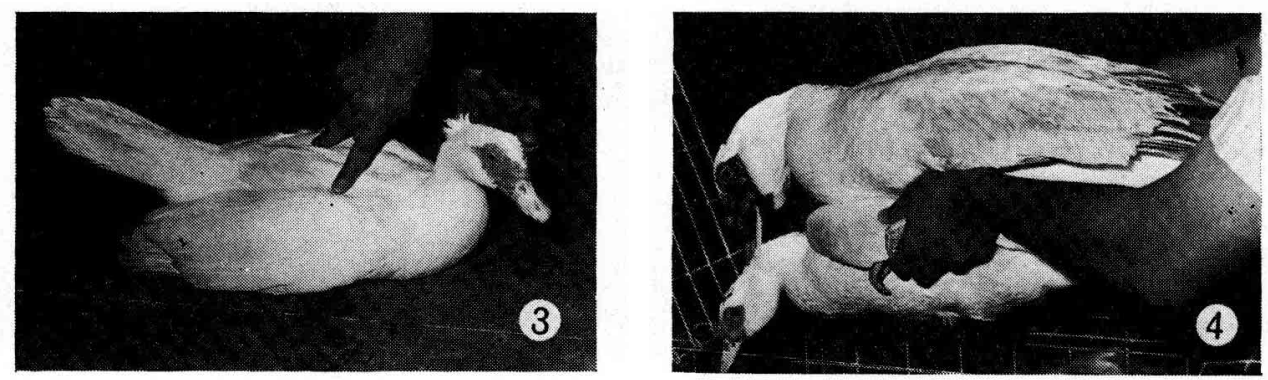

PLOTO 3. Receptive Muscovy female in crouching position

PHOTO 4. The Muscovy duck together with the drake on its back is lifled up during a major adjustment of position 


\section{4. - Intromission, erection and ejaculation}

After a few thrusts, intromission occurs with the drake falling to its left side. The spiral penis becomes erect simultaneously as it penetrates the vagina, followed immediately by ejaculation. WATANABE (I96I) stated that erection occurs before intromission but my observations do not confirm this.

\section{5. - Post-coital display}

After ejaculation, the Pekin male usually displays bridling and "nod-swims" around the duck (LoRENZ, I95I) followed by preening. Post coital display may occur before preening for the Muscovy - he strides with partially open wings around or away from the mated duck, rubbing his head and neck on his shoulders.

\section{II. - Semen Collection with Trained Drakes}

\section{a. - Choice of teaser ducks}

Laying Muscovy females or those about to lay are used as teasers as they are receptive to both Pekin and Muscovy males. The receptive females will crouch and remain in that position when the male makes the grabbing movement or when pressure is applied to her back (Plate I, Photo 3). However, it is seldom possible to use the Pekin duck in this role since Mallard-type ducks will crouch and remain in that position only after courtship. In addition, teaser ducks need to be large enough to support the males (especially for the heavy Muscovy), otherwise collection becomes difficult, if not impossible.

\section{b. - Introduction of the teaser}

After the introduction of the teaser, any exploratory or courtship behaviour of the male should not be interrupted. The drakes are generally more sensitive at this stage than at any of the following stages of mating to any inhibitory factors or sudden movement of the collector. Once the male has mounted and positioned himself, any adjustments to make collection easier are made by the collector. The most convenient position for semen collection is to have the mounted pair in the centre and directly below the opening of the cage. This is done by shifting. the duck gently together with the male where a minor adjustment is required. In the case of a major adjustment, the duck, together with the male on its back, is lifted to the required position (Plate I, Photo 4). At no time must the male be handled or lifted away from the duck.

Often the excited Muscovy male will try to seize the female before it is introduced into the cage, baring its claws and flapping its wings. This makes it impossible to place the teaser at the centre of the cage - hence the need for a major adjustment of position. The smaller and less aggressive Pekin requires only a minot adjustment since the teaser may be placed at the most convenient position for collection. This is fortunate as the Pekin male seldom tolerates being lifted in this manner. 
PIATE 2

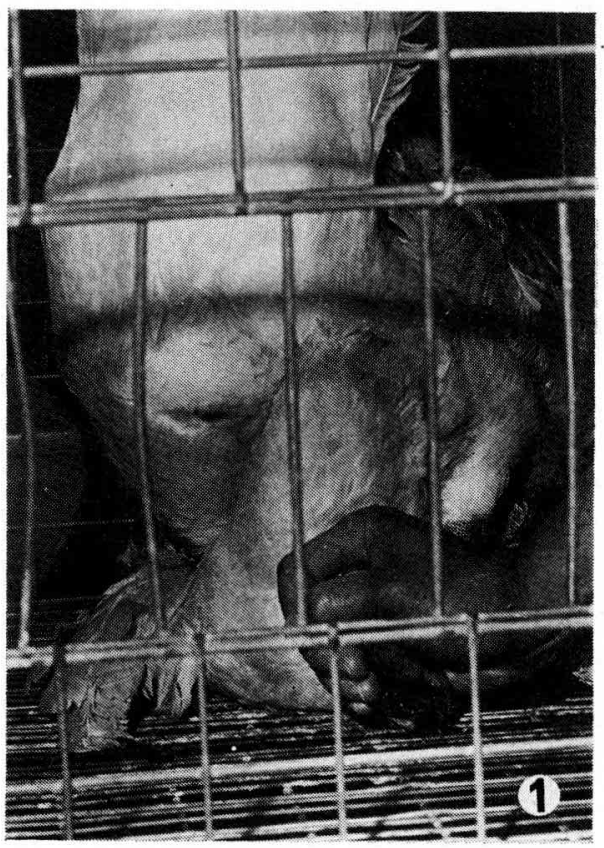

PHOTO I. Collection tube together with the thumb and forefinger of the operator stimulating the duck's cloaca

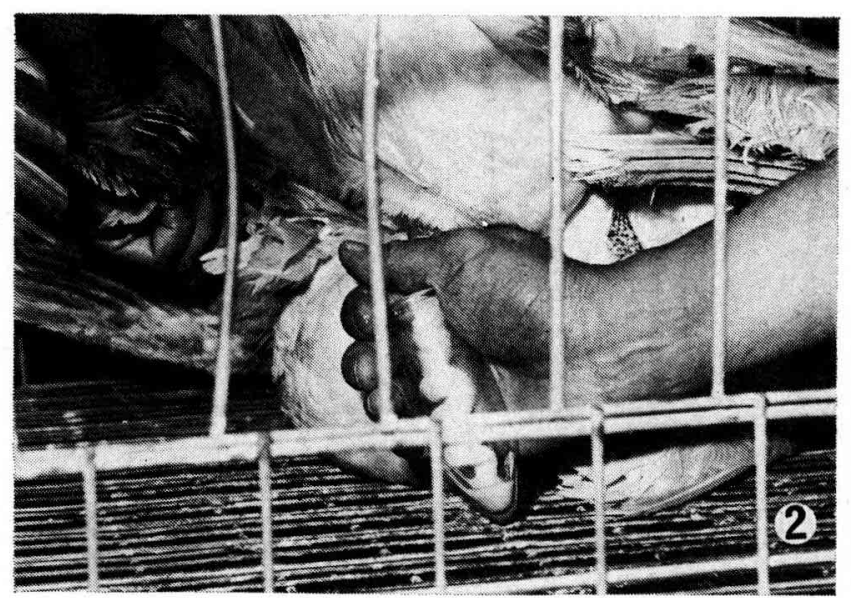

PHoTo 2. Drake ejaculating into the collection tube 


\section{c. - Semen collection}

As soon as the Muscovy male swings its tail from the left to locate the duck's vent, the collection tube is introduced - or, in the case of the Mallard-type ducks, as soon as the male is properly mounted since it ejaculates very rapidly after mounting. The collection tube, which consists of a thick glass centrifuge tube (length ror $\mathrm{mm}$, external diameter $36 \mathrm{~mm}$, internal diameter $29.5 \mathrm{~mm}$ ) is held close to the duck's cloaca at an angle of approximately $45^{\circ}$ (Plate 2, Photo I). The thumb and forefinger of the operator simulates the duck's cloaca. The collection tube is brought close to the male's cloaca as he tries to locate the female's vent. While the male is exerting the pendulum movement, he must not swing beyond the depression formed by the thumb and the forefinger, otherwise he will ejaculate outside the collecting tube. Neither should the collection tube be placed too close to the male's cloaca as it causes the male to thrust repeatedly without intromission and ejaculation. If repeated, the drake may develop internal inhibitions.

After a few thrusts, intromission occurs (Plate 2, Photo 2). As the drake ejaculates, gentle pressure is applied on the penis with the thumb and forefinger. This ensures a good collection and minimizes contamination with faeces and uric acid. Unlike most domestic animals, temperature and pressure of the collection tube are unimportant to the drake. However, the collection tube is usually maintained at $35^{\circ}-3^{\circ}$ in winter and spring to prevent cold shock.

The mean semen volume, concentration and number of spermatozoa/ejaculate of forty I3-month-old Muscovy males was $1.08 \pm 0.06 \mathrm{ml}, \mathrm{I} .93 \pm 0 . \mathrm{I} 3$ $\times \mathrm{IO}^{9} / \mathrm{ml}$ and $2.086 \pm 0.229 \times$ IO $^{9}$ respectively.

When repeated thrusting has become a habit, the male is allowed to mate naturally to prevent the development of internal inhibitions. However, where a male has thrusted repeatedly and then ejaculated, the semen is frequently contaminated with faecal material. Furthermore, with repeated thrusting, the volume of semen collected is ustrally low.

\section{III. - Training of the Drakes}

a. - Settling in

Muscovy drakes are caged separately and learn within one-two days that they are not vulnerable to attack from males on either side. Males are usually brought in on the same day since a timid male placed next to an established male may not mate at all. Although the Pekin drakes are not as aggressive as the Muscovy males, they too are caged separately to prevent homosexual raping of the subordinate male.

\section{b. - The training process}

As soon as the collector is able to move around the cages without upsetting the drakes (i.e. the Muscovy remains quiet and undisturbed, or the Pekin dœs not jump excessively) training commences. The female Muscovy is introduced into the cage. If the male mounts, it is allowed to copulate with the collector standing close behind. After mating the female is removed. For a wary but keen male (most Pekin males fall into this category) the collector must stand at 
a distance acceptable to the male while he mates. Where no response is obtained, or mounting only is attempted, the female is left with the male for the day.

The response of the drakes to training varies considerably. The collector must move quietly and patiently, adapting to the temperament of the drakes.

After 2-3 successful matings the drake will associate the collector with sexual gratification. He comes excited as soon as he sees the collector approaching with the teaser duck (Plate I, Photos I and 2). At this point the drakes are ready for semen collection.

Where a male has ejaculated on three consecutive occasions or on three out of four attempts, it is classed as a successful candidate. The interval between consecutive training periods is I-2 days. To reinforce the drake's newly-acquired skill, two further training periods are given to it within a week. A male is classed as a failure if he did not respond when the teaser was introduced on three separate occasions or did not remain mounted as the collector approached with the collection tube.

\section{IV. - Experimental: The Effect of Pre-Training Management on the Success Rate of Drakes Trained for Semen Collection}

During the process of training males for semen collection, $X$ have observed that males which were in contact with the collector at an early age were more responsive to the training process. To test this, an experiment was designed to study the effect of pre-training management on the success rate of training.

\section{Material and methods}

One hundred and thirty-two Muscovy males were subjected to three different management regimes prior to training. These were : of age.

Regime A - 60 males reared in close contact with the collectors from $\mathrm{I} 6$ weeks

Regime B - 36 males which come into contact with the collectors at puberty. as adults.

Regime C - 36 males (I year old) which came into contact with the collectors

For the Pekin males these were:

Regime A - Io males reared in the collector's presence from 9 weeks of age.

Regime C - I5 males ( 1 year old) which came into contact with the collector as adults.

Young males (I6 weeks old for the Muscovy and 9 weeks old for the Pekin) were reared with females in pens where they were in close contact with the collectors. The young drakes were caged separately as soon as they showed signs of sexual activity (22-24 weeks for the Muscovy and I9-2I weeks for the Pekin). Males brought in directly from Kelmscott Farms Pty Ltd were immediately caged separately. The training for semen collection with the collection tube commenced as soon as the drakes had settled down and accepted the presence of the collector. This usually took 2-3 days for Muscovy males and 5-6 days for 
Pekin males which had prior contact with the collectors and 4-6 days and 8-Io days respectively for males brought in from Kelmscott Farms.

Feed (Finisher and Breeder rations respectively) and water were offered ad libitum to the young birds and breeders.

\section{Results}

Pre-training management had a beneficial effect on the success rate in the training of males for semen collection (Table $I$ ). The success rate for Muscovy males in Regime A and Regime B was significantly greater than in Regime C $\left(\mathrm{X}^{2}=6 \mathrm{I} .4^{0} ; \mathrm{P}<0.00 \mathrm{I}\right)$, but the difference between Regimes $\mathrm{A}$ and $\mathrm{B}$ was not significant $\left(\mathrm{X}^{2}=\mathrm{I} .00 \mathrm{NS}\right)$.

TABLE I

Effect of pre-training management on the success rate in drakes trained for semen collection

Effet des conditions d'élevage sur le taux de réussite des collectes de sperme chez le canard

$\Lambda=$ contact avec l'expérimentateur lors de la fin de la période de croissance des mâles.

$B=$ contact avec l'expérimentateur a la puberté.

$\mathrm{C}=$ contact avec l'expérimentateur a l'âge adulte ( $\mathrm{I}$ an).

\begin{tabular}{|c|c|c|c|c|c|c|}
\hline \multirow{2}{*}{ Regime } & \multicolumn{2}{|c|}{ Total No. of Birds } & \multicolumn{2}{|c|}{ Success (Nos) } & \multicolumn{2}{|c|}{ Failure (Nos) } \\
\hline & Muscovy & Pekin & Muscovy & Pekin & Muscovy & Pekin \\
\hline 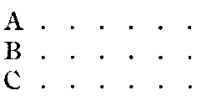 & $\begin{array}{l}60 \\
36 \\
3^{6}\end{array}$ & $\frac{\text { IO }}{\text { I5 }}$ & $\begin{array}{r}55(91.7 \%) \\
30(83.3 \%) \\
6(16.7 \%)\end{array}$ & $\begin{array}{c}8(80.0 \%) \\
9(60.0 \%)\end{array}$ & $\begin{array}{r}5(8.3 \%) \\
6(16.7 \%) \\
30(83.3 \%)\end{array}$ & $\begin{array}{l}2(20.0 \%) \\
6(40.0 \%)\end{array}$ \\
\hline
\end{tabular}

\section{Discussion}

The training procedure and the success rate of training, especially with the young males of both genera, indicate that this method of semen collection may be used for routine AI of ducks. In the past, the large scale production of Muscovy $\times$ Mallard-type hybrid has been hampered by the lack of a reliable method of semen collection from Muscovy males. ONISHI and Kato (I955) and WATANABE (I959) reported that Muscovy males do not respond to massage. Kamar (r962), however, managed to collect semen from the Sudani (Muscovy) drakes by the massage technique. But KAMAR did not give any information on the success rate of training. In Taiwan, where this hybrids is produced in large numbers, HUANG and CHow (I974) have successfully collected semen from Muscovy males with teaser ducks, but manual manipulation is required to evaginate the drake's penis. This method was first reported by ONISHI and KATO (I955). However, ONISHI and Kato (1955) and HuANG and Chow (I974) did not give any quantitative information on the reliability of their method of semen collection.

For the two breeds, the earlier the young males come into contact with the 
collector, the greater the success rate during training. In addition, with the Muscovy males, the training may be shortened without greatly affecting the success rate (Regime A). However, these young males were often awkward for the first collection and some may even attempt to mount the teaser from an improper position. This was not evident in the Pekin males which had 2-3 successful natural matings.

With the young males of both breeds, those classed as failures usually showed no response. With the older males, I4 p. Ioo of the Muscovy and 50 p. Ioo of the Pekin attempted to mount or mounted the teaser but retreated to the corner of the cage whenever the collector approached them.

The relationship between the drake and the collector appears to involve two stages. Up to the point of collection the drake appears to be identified with an individual collector. However, after a number of matings, the majority of trained drakes will mate for any experienced collector since they have associated the collector with sexual gratification.

Although the number of Pekin males in Regime $\mathrm{C}$ was small, they had a greater success rate than the Muscovy males. I have observed that Pekin males have greater libido than Muscovy males of the same age. It may account for their ability to overcome the internal and external inhibitions and be successfully trained.

The volume and concentration of the semen reported in this paper is generally much greater than that reported in the literature for Muscovy males. ONISHr and KATO (I955) and HUANG and CHOW (I974) obtained volumes of $0.82 \mathrm{ml}$ and I.I $7 \mathrm{ml}$, and concentrations of $0.58 \times \mathrm{IO}^{9}$ spermatozoa $/ \mathrm{ml}$ and $\mathrm{I} .34 \times 10^{9}$ spermatozoa/m1 respectively. In addition, KAMAR (I 962 ) reported that the semen volume and sperm concentration of Muscovy Males obtained by massage was $0.18 \mathrm{ml}$ and $3.63 \times 10^{9} / \mathrm{ml}$ respectively. But this very low volume and highly concentrated semen is probably an artifact of the collection technique per se.

Accepté pour publication en mars ıg80.

\section{Acknowledgements}

I am grateful to Professor D.R. LINDSAy and Dr D.E. ROBERTSON for their advice and guidance, to Professor J.P. SIGNOREr for his helpful suggestions concerning the preparation of this manuscript and for the French summary, to $\mathrm{Mr}$ A. ERDMAN for assistance in training the drakes, and to Mr R. VAN BAREN for taking and developing the photographs.

The project was supported in part by a grant from Kelmscott Farms Pty Ltd.

\section{Résumé}

\section{Méthode de collecte du sperme chez le canard}

La mise en ceuvre de l'insémination artificielle chez le canard est particulièrement utile pour l'obtention d'hybrides Pékin $\times$ Barbarie. Les techniques classiques de massage utilisées chez les oiseaux, de même que l'électro-éjaculation ne permettent pas d'obtenir régulièrement une semence de qualité satisfaisante. La méthode proposée consiste, comme chez les mammifères domestiques, à réaliser la collecte alors que la réaction sexuelle du mâle est provoquée par la présentation d'une femelle réceptive. L'éjaculation complète est obtenue par pression du pouce et de l'index lorsque le pénis du mâle est évaginé. Le sperme est recueilli dans un tube maintenu a température convenable. Le volume moyen est $\mathrm{I}, 08 \pm 0,06 \mathrm{ml}$, la concentration $\mathrm{I}, 93 \pm \mathrm{I}, \mathrm{I} 3$ 
$\times$ I ${ }^{9}$ et le nombre total $2,086 \pm 0,229 \times 10^{9}$ sperınatozoïdes (40 mâles Barbarie adultes collectés une fois chacun).

Le choix de la femelle stimulus, les conditions d'élevage des mâles (cages individuelles) et surtout l'entraînement à la présence de l'observateur semblent essentiels à la réussite.

Une expérience portant sur 132 mâles Barbarie montre qu'un contact précoce et fréquent avec la personne qui effectue les collectes conditionne le succès : lorsque les mâles sont en contact avec l'expérimentateur à partir de l'âge de 16 semaines, ou à la puberté, 83 et $9 \mathrm{r}$ p. Ioo d'entre eux, respectivement, peuvent être récoltés, contre seulement i6 p. Ioo lorsque le contact n'a lieu qu'à l'âge d'un an. Les améliorations obtenues par contact précoce sur un faible échantillon de mâles Pékin sont moins marquées et non significatives, le taux d'échecs passant de 40 à 20 p. soo.

\section{References}

Cassagne B., Querrioux J., Latriè P. and Pifkrót R., I973. Quelques aspects de la production du canard mulard. Bull. Tech. Inf. 282, 699-704.

Cheimonska B., Galuszka H. and Lisiecki J., 1962. Electro-ejaculation in drakes. Medycyna Wet. 18, 7 I 2-7I4. (Pol).

Chelmonska B. and Galuszkowa H., i 966 . Observation on collection of semen drakes by massaging the dorsal ventral regions of the body. Zesz. probl. Postep. Nank roln., 61, $273^{-2} 27$. (Pol).

Deiscoer J., 1964. The Water/owl of the World, Vol. 4 : I66. Country Life Ltd. London.

HUANG H. H. and Chow T. C., I974. Artificial insenination in mule duck production. Proc. $X V$ th Wld's Poult. Congr. New Orleans, pp. $26 \mathrm{r}-262$.

KAliva R., I958. Crossing of Pekin ducks and Muskovy ducks. Sb Csl. Akad. Zemed. led, Zivoc Vyr 3 (3I), 503-5I4. (Czech).

KAMAR G. A. R., I962. Semen characteristics of various breeds of drakes in the subtropics. J. Reprod. Fertil. 3, 405-409.

KERRUISH B. M., I955. The effect of sexual stimulation prior to service on the behaviour and conception rate of bulls. Br. J. Anim. Behav. 3, 125-13o.

Lorenz K., I95I. Comparative studies on the behaviour of Anatinae. Avicult. Mag. 51, 157-182.

LoRENZ K., 1953. Comparative studies on the behaviour of Anatinae. Avicult. Mag. 59, $24-34$.

Nismyama H., Nakashima N. and Fukinara N., 1976. Studies on the accessory reproductive organs in the drake. I. Addition to semen of the fluid from the ejaculatory groove region. Poult. Sci. 55, 234-242.

Onishi N. and KATo Y., I955. On mule duck production by means of a new artificial insemination technique. Bull. natn. Inst. agric. Sci. (Chiba), G, 11, I7-31. (Jap)

PINGEL, H., I972. Ein Beitrag zur kunstlichen Besamung in der Entenzucht Wiss. Z. Humboldt Univ. Berl., Mathematische-Naturwissenschaftliche Reihe 21 (2), I 79-I 8I.

Schutz von F., I965. Sexuelle Prägung bei Anatiden. Z. Tierphychol. Tierpsychologie 22, $50-103$.

STEKLEN'OV F. P., KROMIN V. S. and Gavrisil A. P., I976. Meat production of Muscovy $\times$ Pekin hybrid ducks. Visnik. Sil's kogospodars' koi' Nanki (I976) No. 2, 69-63, I2 I (Uk). Anim. Breed. Abstr. 1977, 45, No. 3472.

TAN N. S., I97r. Growth and development of the Muscovy (Cairina moschata) $\times$ Pekin (Anas platyrhynchos) and its reciprocal hybrid. Honouns Thesis, University of Western Australia. $84 \mathrm{pp}$.

WATANABE M., 1957. An improved technique of the artificial insemination in ducks. J. Fac. Fish. Anim. Husb., Hiroshima Univ. 1, 363-368.

Watanabe M., I959. Partial infertility of intergenetic hybrid eggs between the Muscovy drake and the common duck. J. Fac. Fish. Anim. Husb., Hiroshima Univ, 2, 375-384.

WATANABE, M., I96r. Experimental studies on the artificial insemination of domestic ducks with special reference to the production of mule ducks. J. Fac. Fish. Anim. Husb., Hiroshima Univ. 3, 440-478.

Wood-Gush D. G. M., I954. The courtship of the Brown Leghorn cock. Br. J. Anim. Behav. 2, 95-IO2.

Woop-Gush D. G. M., I956. The agonistic and courtship behaviour of the Brown Leghorn cock. Br. J. Anim. Behav. 4, \33-142. 